\title{
Unchain my Heart... Religious Coping and Well-Being in a Forensic Psychiatric Institution
}

\author{
Jos Pieper \& Marinus van Uden
}

\begin{abstract}
In this paper, we will present some results of a study among patients in a forensic psychiatric hospital in The Netherlands. We will focus on the following issues: the patients' general religious beliefs and activities; the patients' religious coping activities; the patients' well-being; the relationship between general religious beliefs and activities, religious coping activities and well-being. We will compare the results among this population with the results of our earlier research in various other psychiatric settings.
\end{abstract}

Keywords

Religious Coping, Well-Being, Forensic Psychiatric Hospital

\section{Introduction}

As the psychology of religion developed at the end of the 19th century, the relationship between religion and mental health was already a main topic. James, Hall, Leuba and Starbuck studied questions like: 'Is conversion a sign of pathology or is it, on the contrary, an attempt to integrate an unstable self?' and 'To what degree are intense religious and mystical experiences connected to mental health or to what degree to psychopathology?' Recent empirical studies suggest 'that religious commitment may play a beneficial role in preventing mental and physical illness, improving how people cope with mental and physical illness, and facilitating recovery from illness' (Matthews, McCullough, Larson, Koenig, Swyers \& Greenwold Milano, 1998, 118).

In line with this tradition, we have been studying, for about a decade, the influence of religion on the lives of people suffering from mental health problems. Because of the lack of empirical evidence in The Netherlands regarding this question, we started a research project among outpatients in 1992 (Pieper \& Van Uden, 1993abc, Van Uden \& Pieper, 1996). We studied several groups of 
outpatients. At that time, we were interested particularly in the degrees of positive versus negative influence of religion on mental problems. Our main conclusions were: in $39 \%$ of cases, religion has a positive influence on mental problems; in about $36 \%$ of cases, religion has a negative influence on mental problems. We also studied several groups of inpatients (Pieper \& Van Uden, 2005). Here, the positive influence was even more evident: $54 \%$ positive influence and $16 \%$ negative influence. The positive influence could be understood in line with Pargament's religious coping theory (Pargament, 1997). For religious people in times of mental crisis, religion is a powerful tool for managing this crisis. Other authors have come to similar conclusions. 'Religion may serve as a pervasive and potentially effective method of coping for persons with mental illness, thus warranting its integration into psychiatric and psychological practice' (Tepper, Rogers, Coleman \& Newton Malony, 2001, 660). Fitchett, Burton and Sivan (1997) found that a large majority of the psychiatric patients they studied turned to religion during hospitalisation. Kirov, Kemp, Kirov \& David (1998) found that about $60 \%$ of the psychotic inpatients they studied used religion to cope with their disorder. Yangarber-Hicks (2004) studied psychiatric patients in Ohio. His findings indicated that religious coping was related to a greater involvement in recovery-enhancing activities and increased empowerment.

In this paper, we will present some results of a new study among patients in a forensic psychiatric hospital in The Netherlands. We will focus on the following issues:

1. To what degree did patients practise religious coping activities?

2. To what degree were religious coping activities beneficial to the patients' wellbeing (expressed in less anxiety and more existential well-being)?

3. To what degree was well-being influenced by the general religiosity of the inpatients and to what degree by their specific religious coping activities?

With respect to this last question, Pargament, Ensing, Falgout, Olsen, Reilly, Van Haitsma \& Warren (1990) and Pargament, Olsen, Reilly, Falgout, Ensing \& Van Haitsma (1992) and also Jenkins \& Pargament (1995) have argued that situation-specific measures of religiousness would be stronger predictors for the resolution of specific life events (in this study: being hospitalized in a forensic psychiatric hospital), than generalized measures of religiousness. They have proposed a model of religious coping efforts being mediators of the relationship between general religious orientations and the outcomes of specific life events. 


\section{Method}

\section{Participants and Procedure}

In 2005, we studied patients of the Pompe Clinic, a forensic psychiatric hospital in The Netherlands. As research technique we used questionnaires. 120 patients were addressed. 52 questionnaires were returned; i.e. a response rate of $43.3 \%$. The age of the participants ranged from 24 to 67 years, with a mean of 42.7 years $(\mathrm{N}=51)$. The median was 41 years. All participants were male. We were unable to carry out a non-response investigation, but it seemed reasonable to suppose that religious and more educated patients are over-represented. All participants were informed about the purpose of the study and all agreed to participate voluntarily. Furthermore, we offered pastoral care in case filling in the questionnaire would raise serious existential questions.

\section{Measures}

\section{General Religious Characteristics}

We asked about religious socialisation, membership of a religious congregation, church attendance, private religious activities and intrinsic religiosity. We used a short version of Hoge's (1972) original intrinsic religiosity scale for measuring the degree of intrinsic religiosity. This is the Duke Religion Index (Koenig, Parkerson \& Meador, 1997), consisting of three items (5-point Likert scale).

\section{Religious Coping: Pargament's Three Coping Styles}

Pargament, Kennell, Hathaway, Grevengoed, Newman \& Jones (1988) referred to three ways in which people can deal with issues of responsibility and control in religious coping activities: self-directing, deferring and collaborative. In the self-directing style, it is the individual's own responsibility to solve problems. The individual assumes an active problem-solving stance. In the deferring style, individuals defer the responsibility of problem-solving to God. They wait for solutions to emerge through God's active efforts. In the collaborative style, responsibility for the problem-solving process is held jointly by the individual and God. Both are working together to solve problems. Pargament et al. (1988) developed a questionnaire to measure these coping styles. The short version of this questionnaire was translated into Dutch by Alma (1998). Some of Pargament's statements had to be reformulated, due to differences between the American and the Dutch contexts. This translation has also been used in the present 
research. The questionnaire consists of 18 statements, 6 for each coping style. The response categories are: $1=$ never; 2 = seldom; 3 = occasionally; $4=$ often; $5=$ always.

\section{Religious Coping: Positive and Negative Influence}

Pargament's coping styles represent different kinds of problem-focused coping. In our questionnaire, we also tried to measure religious coping in another way. We did not focus on problem-solving, but instead we focused on enduring the situation and managing the emotional distress associated with it, for instance by conveying meaning to it and looking for social support. Theoretically, the effectiveness of religious coping activities could be summarized briefly as follows: they establish social integration and support; they establish a personal relationship to a divine other; they provide systems of meaning and existential coherence; and, finally, they promote specific patterns of religious activity and personal life style (Daaleman, 1999). Thus, social, affective, cognitive and behavioural aspects are involved. These four aspects were operationalized with two items each (see section 'Results' below). However, religion can also have a negative influence on coping with problems. We used 7 items to measure this negative effect (see section 'Results' below). The response categories were: ' $1=$ yes; 2 = somewhat and $3=$ no'.

\section{Receptive Coping}

In The Netherlands, Alma, Pieper and Van Uden (Alma, Pieper \& Van Uden, 2003; Van Uden, Pieper \& Alma, 2004) have criticized Pargament's three coping styles. They argued that an image of God as a person is not always appropriate in more secularized countries. Furthermore, they argued that people do not always look for an active, intervening God. Therefore, they developed a new coping scale: the Receptivity Scale. This scale does justice to a more impersonal view of God. Moreover, the scale takes into account that people are not always directly focused on problem-solving, either with or without God. A receptive attitude might allow them to be open to what they cannot control. When confronted with a problematic situation, people can be open to what might be in store for them. The scale consists of 8 items. Examples are, 'In difficult situations, I open myself to solutions that arise', 'In solving my problems, I am sometimes struck by the fact that things just fall into place', and 'After a period of difficulties, the deeper significance of my problems will be revealed to me'. In earlier research, it was shown that this scale correlates with a belief in a transcendent reality (Van Uden, Pieper \& Alma, 2004). The response categories were: $1=$ never; $2=$ seldom; $3=$ now and then; $4=$ often; $5=$ always. 


\section{Psychological Well-being: Degree of Anxiety}

Psychological well-being was measured with a psychological scale, the ZBV ('Zelf Beoordelings Vragenlijst, Self Assessment Questionnaire'). The ZBV is a self-examination questionnaire, used to determine the amount of anxiety present. It is the Dutch version of the STAI, Spielberger's "State-Trait Anxiety Inventory" (Van der Ploeg, Defares \& Spielberger, 1980). The ZBV consists of two separate questionnaires, measuring two distinct concepts of anxiety: State Anxiety and Trait Anxiety. As we were interested in long-term effects rather than in shortterm ones, we opted for the Trait Anxiety scale. This scale consists of twenty statements like, 'I feel fine' and 'I feel nervous and agitated'. Ten statements are formulated symptomatically positive and ten symptomatically negative.

\section{Spiritual Well-being}

In this study, we used the Spiritual Well-Being Scale (SWBS) in order to further explore the relationship between religion, religious coping and existential and psychological well-being. Paloutzian and Ellison have developed the SWBS, noting that there had been little attention for the spiritual and existential aspects of people's lives as a quality of life indicator (Scott, Agresti \& Fitchett, 1998). The scale consists of two dimensions: a vertical dimension, assessing one's relationship to God (the Religious WBS), and a more horizontal dimension, assessing life purpose and meaning in life (the Existential WBS). Ten statements are used to measure each dimension. The American studies used a 6-point Likert scale for answering the statements; we used a 5-point Likert scale, because many of the other scales in the questionnaire were 5-point Likert scales. The patients could give the following answers: 1 = strongly agree; 2 = agree; 3 = neither agree nor disagree; $4=$ disagree; $5=$ strongly disagree.

\section{Results}

\section{General Religious Characteristics of the Sample}

The majority of the patients had been socialized in a religion or faith: $63 \%$ answered 'yes' and $8 \%$ 'somewhat', with only $29 \%$ answering 'no' ( $\mathrm{N}=52)$. In their present lives, $43 \%$ of the patients were members of a religious congregation, $45 \%$ were not and $12 \%$ couldn't make up their minds $(\mathrm{N}=49)$. In comparison: A sociological study, the European Social Survey, showed that of Dutch citizens in general in 2002, $44 \%$ were members of a church or religious congregation (Becker \& De Hart, 2006, 12). Before they were hospitalized, $80 \%$ of our 
respondents sometimes attended church or other religious ceremonies: $42 \%$ of the patients went to church weekly, $10 \%$ once a month, and $28 \%$ only a few times a year, $20 \%$ never attended church $(\mathrm{N}=50)$. How often did they perform private religious activities, like prayer or meditation? $46 \%$ performed these activities with some frequency: $15 \%$ several times a day, $17 \%$ almost every day and $14 \%$ regularly. $15 \%$ sometimes performed these private religious activities, and $39 \%$ seldom or never $(\mathrm{N}=52)$. The mean score of the Duke Religion Index, measuring intrinsic religiosity, was 2.84 . Hence, a slight majority of this sample was intrinsically motivated.

\section{Pargament's Three Coping Styles}

From these three styles, scales were constructed with reliable alphas of 0.89 (selfdirecting), 0.94 (collaborative) and 0.94 (deferring), respectively. The self-directing scale scored highest with 3.31 , followed by the collaborative scale (2.75) and the deferring scale (2.28). In general, the scores on these problem-focused styles were not high. The patients used them at best 'occasionally'. From Pargament's study it appeared that the styles are interconnected. This study, too, showed a clear correlation. There was a positive correlation of $0.85(\mathrm{p}<0.01)$ between the deferring and collaborative styles. In both styles, God played an important role. The self-directing style contrasted with the other two styles: with the deferring style $(\mathrm{r}=-0.59 ; \mathrm{p}<0.01)$, but even more so with the collaborative style $(\mathrm{r}=-0.79 ; \mathrm{p}<0.01)$.

\section{Religious Coping: Positive and Negative Influence}

First, we asked in a global sense about the positive and negative influence of religion on coping with problems. The answers were as follows. Positive influence: $15 \%$ totally agreed; $35 \%$ agreed; $29 \%$ neither agreed, nor disagreed; $6 \%$ disagreed; $15 \%$ totally disagreed $(\mathrm{N}=52)$. Negative influence: $2 \%$ totally agreed; $6 \%$ agreed; $31 \%$ neither agreed, nor disagreed; $37 \%$ disagreed; $25 \%$ totally disagreed $(\mathrm{N}=52)$.

Hence, religion clearly had more a positive than a negative influence: $50 \%$ experienced a positive, $8 \%$ a negative influence. In comparison: in our research among psychiatric inpatients in The Netherlands, almost the same figures appeared: $54 \%$ reported a positive influence of religion, $16 \%$ a negative influence. Research among outpatients in 1992 showed more of a negative influence of religion: $39 \%$ experienced a positive, $36 \%$ a negative influence on psychological problems (Pieper \& Van Uden, 1993a). It is interesting to know that there was no 
negative relationship between positive and negative influences. Both influences could be present simultaneously.

Next, we asked which aspects of religion caused this positive influence. Table 1 shows which positive aspects are at stake.

Table 1. Positive influence because.... (\%) $(\mathrm{N}=49-50)$

\begin{tabular}{lccc}
\hline & yes & somewhat & no \\
\hline $\begin{array}{l}\text { One can visit a pastoral counselor. } \\
\text { Fellow believers provide support. }\end{array}$ & 57 & 25 & 18 \\
$\begin{array}{l}\text { Because of my relationship with God, I am not } \\
\quad \text { on my own. }\end{array}$ & 47 & 20 & 33 \\
$\begin{array}{l}\text { My religion provides meaning. } \\
\begin{array}{l}\text { Prayer and meditation do help in coping with my } \\
\quad \text { problems. }\end{array}\end{array}$ & 46 & 28 & 26 \\
$\begin{array}{l}\text { Religious rituals, like praying and church } \\
\quad \text { attendance, give me something to hold on to. }\end{array}$ & 43 & 26 & 36 \\
$\begin{array}{l}\text { My religion offers security. } \\
\text { Through my faith I can give some meaning to my }\end{array}$ & 42 & 20 & 38 \\
$\quad$ problems. & 39 & 22 & 39 \\
\hline
\end{tabular}

The most positive influence related to the social aspects of religion (support of a pastoral counselor and fellow believers). The affective dimension (relationship with God) and the cognitive dimension (meaning giving) also had a positive influence. This also applied to the ritual dimension: participating in collective (church attendance) and private rituals (praying).

Table 2 shows the negative aspects.

Table 2. Negative influence because.... (\%) $(\mathrm{N}=47-48)$

\begin{tabular}{|c|c|c|c|}
\hline & Yes & somewhat & no \\
\hline $\begin{array}{l}\text { Religion emphasizes humility, servitude and } \\
\text { sacrifice. }\end{array}$ & 25 & 27 & 48 \\
\hline Religion emphasizes guilt and feelings of guilt. & 21 & 28 & 51 \\
\hline $\begin{array}{l}\text { Religion emphasizes shame and feelings of } \\
\text { shame. }\end{array}$ & 17 & 27 & 56 \\
\hline Because I lost my religious orientation. & 15 & 25 & 60 \\
\hline
\end{tabular}


Table 2. (cont.)

Yes somewhat

Religion upsets me and makes me anxious.

13

10

77

Religion provides a negative view of life and the

10

21

69 future.

Religion affects my autonomy.

The emphasis on humility and guilt were the most important negative influences of religion.

The mean of all 8 positive coping items, on a scale from yes $(=1)$, a little $(=2)$ and no $(=3)$, is 1.84 (alpha $=0.89)$. The mean of all 7 negative coping items is 2.47 (alpha $=0.81)$. Hence, the positive influence was situated between 'yes' and 'a little', the negative influence between 'a little' and 'no'.

\section{Receptive Coping}

Table 3 shows the scores on the eight items.

Table 3. Receptive coping (\%) $(\mathrm{N}=41-51)$

\begin{tabular}{|c|c|c|c|c|c|c|}
\hline & 1 & 2 & 3 & 4 & 5 & Mean \\
\hline $\begin{array}{l}\text { In difficult situations I open myself to } \\
\text { solutions that arise. (Factor } 2 \text { ) }\end{array}$ & 12 & 5 & 29 & 33 & 21 & 3.47 \\
\hline $\begin{array}{l}\text { In difficult situations I trust that a way } \\
\text { out will unfold. (Factor } 2 \text { ) }\end{array}$ & 12 & 7 & 43 & 19 & 19 & 3.26 \\
\hline $\begin{array}{l}\text { When I wonder how to solve a } \\
\text { problem, I trust that a solution will } \\
\text { be shown to me in due course. (no } \\
\text { factor) }\end{array}$ & 17 & 12 & 34 & 20 & 17 & 3.07 \\
\hline $\begin{array}{l}\text { When I have problems, I trust that a } \\
\text { solution will be presented to me. } \\
\text { (Factor } 1 \text { ) }\end{array}$ & 20 & 12 & 35 & 14 & 20 & 3.02 \\
\hline $\begin{array}{l}\text { When I am worried, earlier } \\
\text { experiences make me trust that I } \\
\text { will be shown a way out. (Factor } 1 \text { ) }\end{array}$ & 12 & 10 & 52 & 24 & 2 & 2.95 \\
\hline
\end{tabular}


Table 3. (cont.)

$\begin{array}{cccccc}\mathbf{1} & \mathbf{2} & \mathbf{3} & \mathbf{4} & \mathbf{5} & \text { Mean } \\ 20 & 8 & 40 & 22 & 10 & 2.94 \\ 22 & 17 & 34 & 12 & 15 & 2.80 \\ & & & & & \\ 21 & 17 & 33 & 21 & 7 & 2.76\end{array}$

In solving my problems, I am sometimes struck by the fact that things just fall into place. (Factor 2 ) When I find myself in times of trouble, I have faith in the eventual revelation of their meaning and purpose. (Factor 1)

After a period of difficulties the deeper significance of my problems will be revealed to me. (Factor 1)

A Principal Component analysis (with varimax rotation; missing pairwise; mineigen $=1$; factor loading $>0.40$ ) was carried out on the eight receptivity items, yielding two components (explained variance $43.6 \%+21.5 \%=65.1 \%$; $\mathrm{KMO}=0.74$ ). The item 'When I wonder how to solve a problem, I trust that a solution will be shown to me in due course' had a factor loading above 0.40 on both factors. Consequently, it was not used in further analyses.

Cronbach's alpha coefficient was 0.83 for factor 1 and 0.68 for factor 2 . The 4 items of the first factor ('receptive-agent') refer to an active agent that is present and reveals, presents and shows something. The formulation makes it possible to imagine this agent as a more or less personal God. The 3 items of the second factor ('receptive-no agent') seem to refer to opening oneself to fate or the laws of the cosmos. The agent is absent and something reveals itself.

Both factors were transformed into scales. The mean of the 'receptive-agent' scale was 2.87 , that of the 'receptive-no agent' scale was 3.28. Our respondents had more faith in an undefined cosmic power than in a more or less personal god figure.

\section{Psychological Well-being: Degree of Anxiety}

The alternatives for answering were: 'hardly ever,' 'sometimes', 'often' and 'nearly always'. Per item, 1, 2, 3, or 4 points could be scored. Thus, the range of the entire 20 -items scale runs from 20 to 80 points. The symptomatically positive statements were coded inversely. This means: the lower the score on the total scale, 
the lower the trait anxiety. The average score of our sample was $42.6(\mathrm{~N}=47)$. Psychiatric inpatients in a denominational hospital we investigated earlier (Pieper \& Van Uden, 2001) were more anxious. Their average score was 52.

\section{Spiritual Well-being}

Statements indicating religious and existential well-being were somewhat more often endorsed than statements indicating religious and existential doubts. The overall score on the scale underlined this: 2.80 for our sample (negatively worded items were scored inversely). This score was on the positive side of the scale. What does this score mean: is it high or low? In The Netherlands, psychiatric inpatients in a non-denominational hospital scored 2.74 (Pieper \& Van Uden, 2000). And in our study of psychiatric patients in a denominational hospital (Pieper \& Van Uden, 2001), they scored even more positive: 2.61. In that religious sample, religious well-being in particular was high.

The mean of the existential part of the scale (alpha $=0.80)$ was 2.66 . The mean of the religious part of the scale (alpha $=0.90)$ was 2.92 . This means that a majority of the inpatients had a positive relationship with God and was not in an existential crisis.

Both religious and existential well-being were correlated with the time spent in the hospital. Both correlations were $r=-0.30(p<0.05)$. A longer hospitalisation corresponded with less religious and existential well-being.

In this study we used religious well-being as a measure of general religiousness, as a measure of the inpatients' religious resources. We used the existential wellbeing part as a measure of well-being. Low scores on this scale indicate existential well-being.

\section{Religious Coping and Existential and Psychological Well-being}

We will now discuss the relationship between religious coping (Pargament's three coping styles, receptive coping and positive and negative influence) and well-being (existential well-being and psychological well-being: degree of anxiety). Existential well-being correlated with negative religious coping $(\mathrm{r}=-0.42$; $\mathrm{p}<0.01)$, and also with self-directive coping $(\mathrm{r}=0.32 ; \mathrm{p}<0.05)$. Therefore, the absence of religion and a negative influence of religion were related to less existential well-being, but positive religious influence was not related to more existential well-being, although the correlation was almost significant $(\mathrm{p}=0.07)$. Psychological well-being (amount of anxiety) only correlated with negative religious coping $(\mathrm{r}=-0.58 ; \mathrm{p}<0.01)$. Here again it becomes evident that negative 
aspects of religious coping influence well-being, while positive aspects do not. Especially feelings of guilt and shame had a negative effect.

Which variables had more influence on well-being: general religious orientations and activities or religious coping activities? No general religious variables were correlated with anxiety. But two general religious variables related to a better existential well-being: intrinsic religiosity $(r=0.29 ; \mathrm{p}<0.05)$ and religious well-being $(r=0.44 ; \mathrm{p}<0.01)$. Based on the following regression analysis (method: enter), the negative influence of religion is shown to have the most predictive power.

Table 4. Regression Analysis

Dependent Variable: Existential Well-Being

\begin{tabular}{lccccc}
\hline & $\begin{array}{c}\text { Unstan- } \\
\text { dardized } \\
\text { Coefficient }\end{array}$ & & $\begin{array}{c}\text { Standardized } \\
\text { Coefficient }\end{array}$ & t & Sig. \\
\hline \multicolumn{1}{c}{ Model } & $\mathrm{B}$ & Std. Error & Beta & & \\
(Constant) & 30.780 & 6.497 & & 4.738 & .000 \\
INTRINS & $-8.823 \mathrm{E}-02$ & .410 & -.047 & -.215 & .831 \\
RWBS & .180 & .176 & .268 & 1.021 & .316 \\
NEGATIV & -.722 & .296 & -.375 & -2.442 & .021 \\
SELF-DIR & .179 & .184 & .187 & .973 & .338 \\
\hline
\end{tabular}

\section{Conclusions and Recommendations}

\section{Conclusions}

This research concerned 52 patients of the Pompe Clinic, a forensic psychiatric hospital in The Netherlands. We investigated patients aged 24-67 years (mean age 43 years). Their scores on an anxiety scale suggest a degree of anxiety that is definitely lower than the scores of respondents from our earlier research in the field of inpatient psychiatry.

Furthermore, it seems that we are dealing with a more or less average religious group: $63 \%$ of the respondents had had a religious socialisation; $43 \%$ were members of a religious congregation, mostly the Roman-Catholic and the Protestant churches. A small majority of the patients were intrinsically motivated. 
$42 \%$ regularly attended religious services and $46 \%$ regularly performed private religious activities.

From our investigation it becomes clear that there is more positive than negative influence of religion on dealing with problems: $50 \%$ of the respondents experience a positive, only $8 \%$ a negative influence. This is in line with our earlier research results. In comparison: in our research among psychiatric inpatients in The Netherlands, we found the same tendency: $54 \%$ reported a positive influence of religion, $16 \%$ a negative influence. Research among outpatients in 1992 showed a more negative influence of religion: $39 \%$ experienced a positive, $36 \%$ a negative influence on psychological problems (Pieper \& Van Uden, 1993a).

We will now briefly describe some important results from our own research in the past ten years, which we carried out among clients and therapists in community and residential mental healthcare in The Netherlands. When we survey the client data, it is clear that for $39 \%$ (community) to $54 \%$ (residential) of people with mental health problems, faith contributes positively to their coping with their problems. In particular for hospitalized elderly patients, faith is an important source of coping with regard to their psychosocial problems. We have drawn the following conclusion: "Patients who are hospitalised experience their life situation as relatively unchangeable. They lack coping resources focusing upon problem solving. For that reason, they revert to coping resources focusing upon emotionally managing their problems. One of the most important emotionfocused coping resources is religion" (Pieper \& Van Uden, 2001, 39). However, faith can also have a negative influence. This was reported by $36 \%$ of community and $16 \%$ of residential patients.

Our present respondents looked in particular for support from a religious community (support from a pastoral counsellor and fellow believers). In our view, this has to do with the fact that this group of forensic patients experience their hospital as a prison and not as a mental healthcare institution offering safety and protection, as is the case for psychiatric patients in mental healthcare institutions. They miss the contacts with the outside world and try to get some compensation for this in their contacts with a pastoral counsellor or through encounters in church attendance. However, other alternatives that are provided clearly have a positive influence too. However, this positive influence does not yet (just not!) translate into increased existential well-being, nor into a decrease in feelings of anxiety. But there is a correlation with the negative influence of religion: this negative influence is related to more anxiety and less existential well-being (see also Pargament, Zinnbauer, Scott, Butter, Zerowin \& Stanik, 1998).

Pargament distinguishes three ways in which God can play a role in coping with stressful situations. This leads to the description of three coping styles: self- 
directing, deferring and collaborative. The self-directing style scores highest in our group of respondents, followed by the collaborative style and the deferring style. Regarding well-being, only the self-directing style correlated with (less) existential well-being.

In this research we also used another way of measuring religious coping: receptive coping. The Receptivity Scale does justice to a more impersonal view of God. Furthermore, the scale takes into account that people are not always directly focusing on the solution of problems, either with or without God. A receptive attitude might allow them to be open to what they cannot control. Confronted with a problematic situation, people can be open to what might be in store for them. This receptive coping style is divided into two separate factors: 'receptiveagent' and 'receptive-no agent'. The items of the first factor ('receptive-agent') refer to an active agent that is present and reveals, presents and shows something. The formulations make it possible to imagine this agent as a more or less personal God. The items of the second factor ('receptive-no agent') seem to refer to opening oneself to fate or cosmic laws. The agent is absent and something reveals itself. The mean of the 'receptive-agent' scale is 2.87 , of the 'receptive-no agent' scale it is 3.28. Our respondents have more faith in an undefined cosmic power than in a more or less personal god figure. But these coping styles were not correlated with well-being.

Finally, it becomes clear that the influence of all modes of religious coping on well-being (existential and psychological) work through the route of negative religious coping. Hence, the negative aspects of religion have a stronger impact than the positive ones.

\section{Recommendations for Future Research}

Future research should try to avoid several methodological shortcomings of this study.

1. To start with, we need longitudinal designs, as no causal explanations can be provided in this cross-sectional design.

2. Second, newly developed measures of religious coping can be used (Pargament, Koenig \& Perez, 2000).

3. Third, more objective measures of well-being should be used. Our study relied on a self-report measure.

4. Furthermore, it is important to pay attention to the research sample. In our studies, differences in the degree of religiousness led to different relationships between general religiousness, religious coping and well-being. 
Consequently, different theories are needed to understand the coping behaviours of different samples.

5. Finally, we need more fine-tuning between the religious doctrines and experiences of the population under investigation on the one hand, and the religious coping instruments on the other hand. Pargament's three styles as well as the Receptivity Scale may have been less adequate for measuring these forensic psychiatric patients' religious coping activities.

\section{Clinical Implications}

In conclusion, we give some practical recommendations for improving patient care.

1. Pastoral counselors as well as psychologists/psychiatrists should more clearly take into account the positive influence of religion on coping with psychosocial problems. Whilst extensive personality changes are no longer possible, religion still is effective in emotion-focused coping. Especially patients who have to stay in hospital for the rest of their lives (long stay) could benefit from this function.

2. The most effective religious coping function is the social one: contact with pastoral counselors and with other believers. This is in line with the fact that these forensic patients feel socially isolated. In planning their activities, pastoral counselors should be well aware of this.

3. The influence of positive religious coping on existential and psychological well-being did just not reach significance. The influence of negative religious coping did reach significance: less existential well-being and more anxiety. Pastoral counselors should take this finding seriously. When patients emphasize humility, servitude and sacrifice, as well as feelings of guilt and shame, ministers should discuss the level of reality of these attitudes.

4. Psychologists and psychiatrists should know about the effects of religious coping on psychosocial problems. Further training in religion and mental health is to be recommended. The present authors (Pieper \& Van Uden, 2005) have developed a course in 'Religion and Mental Health', that was successfully offered to professionals in mental healthcare.

We hope that these recommendations will help to "unchain the patients" hearts". 


\section{References}

Allport, G.W. (1950). The Individual and his religion. New York: Macmillan.

Allport, G.W. \& Ross, J.M. (1967). Personal Religious Orientation and Prejudice. Journal of Personality and Social Psychology, 5, 432-443.

Alma, H.A. (1998). Identiteit door verbondenheid. Een godsdienstpsychologisch onderzoek naar identificatie en christelijk geloof [Identity through Alliance. A Study in the Psychology of Religion on Identification and Christian Faith]. Kampen: Kok.

Alma, H.A., Pieper, J.Z.T. \& Uden, van M.H.F. (2003). When I Find Myself in Times of Trouble: Pargament's Religious Coping Scales in The Netherlands. Archive for the Psychology of Religion, 24, 64-74.

Becker, J., J. de Hart. (2006). Godsdienstige veranderingen in Nederland. Verschuivingen in de binding met de kerken en de christelijke traditie [Religious Transformations in The Netherlands. Changes in the Attachment to Churches and to Christian Tradition]. Den Haag: Sociaal en Cultureel Planbureau.

Daaleman, T.P. (1999). Belief and Subjective Well-Being in Outpatients. Journal of Religion and Health, 38, 219-227.

Fitchett, G., Burton, L.A. \& Sivan, A.B. (1997). The Religious Needs and Resources of Psychiatric Inpatients. The Journal of Nervous and Mental Disease, 185, 320-326.

Hoge, D.R. (1972). A Validated Intrinsic Religious Motivation Scale. Journal for the Scientific Study of Religion, 11, 369-376.

Jenkins, R.A. \& Pargament, K.I. (1995). Religion and Spirituality as Resources for Coping with Cancer. Journal of Psychosocial Oncology 13, 51-74.

Kirov, G., Kemp, P., Kirov, K. \& David, A.S. (1998). Religious Faith after Psychotic Illness. Psychopathology, 31, 234-245.

Koenig, H.G., Parkerson, G.R. Jr. \& Meador, K.G. (1997). Religion Index for Psychiatric Research. American Journal of Psychiatry, 153, 885-886.

Matthews, D.A., McCullough, M.E., Larson, D.B., Koenig, H.G., Swyers, J.P. \& Greenwold Milano, M. (1998). Religious Commitment and Health Status. A Review of the Research and Implications for Family Medicine. Archive for Family and Medicine, 7, 118-124.

Pargament, K.I. (1997). The Psychology of Religion and Coping. Theory, Research, Practice. New York: The Guilford Press.

Pargament, K.I., Kennell, J., Hathaway, W., Grevengoed, N., Newman, J. \& Jones, W. (1988). Religion and the Problem-Solving Process. Three Styles of Coping. Journal for the Scientific Study of Religion, 27, 90-104.

Pargament, K.I., Koenig, H.G. \& Perez, L.M. (2000). The Many Methods of Religious Coping. Development and Initial Validation of the RCOPE. Journal of Clinical Psychology, 56, 519-543.

Pargament, K.I., Zinnbauer, B.J., Scott, A.B., Butter, E.M., Zerowin, J. \& Stanik, P. (1998). Red Flags and Religious Coping. Identifying some Religious Warning Signs among People in Crisis. Journal of Clinical Psychology, 54, 77-89. 
Pargament, K.I., Ensing, D.S., Falgout, K., Olsen, H., Reilly, B., Haitsma, van K. \& Warren, R. (1990) God Help Me (I): Religious Coping Efforts as Predictors of the Outcomes to Significant Negative Life Events. American Journal of Community Psychology 18, 793-824.

Pargament, K.I., Olsen, H., Reilly, B., Falgout, K., Ensing, D.S. \& Haitsma, van K. (1992). God Help Me (II): The Relationship of Religious Orientations to Religious Coping with Negative Life Events. Journal for the Scientific Study of Religion 31, 504-513.

Pieper, J.Z.T. \& Uden, van M.H.F. (1993a). Ex-cliënten over de Riagg-OZL. Resultaten van een satisfactieonderzoek onder cliënten van wie de behandeling bij de Riagg-OZL te Heerlen in 1991 is afgesloten [Former Clients about the Riagg-OZL. Results of a Satisfaction Survey among Clients whose Treatment in the Riagg-OZL in Heerlen has been Completed in 1991]. Heerlen: Universiteit voor Theologie en Pastoraat.

Pieper, J.Z.T. \& Uden, van M.H.F. (1993b). Ex-cliënten over de Riagg Zwolle. Resultaten van een satisfactieonderzoek onder cliënten van wie de behandeling bij de Riagg Zwolle in 1991 is afgesloten [Former Clients about the Riagg Zwolle. Results of a Satisfaction Survey among Clients whose Treatment in the Riagg Zwolle has been Completed in 1991]. Heerlen: Universiteit voor Theologie en Pastoraat.

Pieper, J.Z.T. \& Uden, van M.H.F. (1993c). Satisfaction Survey among Elderly. Former Clients of the Unit for Elderly Clients about the Riagg OZL.

Pieper, J.Z.T. \& Uden, van M.H.F. (2000). Geestelijke verzorging op Van Gogh. Onderzoek onder cliënten van het Vincent van Gogh Instituut naar hun geloofllevensbeschouwing en naar bun behoefte aan geestelijke verzorging [Pastoral Care at Van Gogh. Research among Clients of Van Gogh regarding their Faith/Worldview and their Need of Pastoral Care]. Venray (external report).

Pieper, J.Z.T. \& Uden, van M.H.F. (2001). Geestelijke verzorging op De Fontein. Onderzoek onder cliënten van De Fontein naar hun geloof/levensbeschouwing en naar hun behoefte aan geestelijke verzorging [Pastoral Care at De Fontein. Research among Clients of De Fontein regarding their Faith/Worldview and their Need of Pastoral Care]. Zeist (external report).

Pieper, J.Z.T. \& Uden, van M.H.F. (2005). Religion and Coping in Mental Health Care. Amsterdam: Rodopi.

Ploeg, van der H.M., Defares, P.B. \& Spielberger, C.D. (1980). Handleiding bij de Zelf-Beoordelingsvragenlijst [Manual of the Self-Assessment Questionnaire]. Lisse: Swets \& Zeitlinger.

Scott, E.L., Agresti, A.A. \& Fitchett, G. (1998). Factor Analysis of the 'Spiritual Well-Being Scale' and its Clinical Utility with Psychiatric Inpatients. Journal for the Scientific Study of Religion, 37, $\underline{314-321 .}$

Tepper, L., Rogers, S.A., Coleman, E.M. \& Newton Malony, H. (2001). The Prevalence of Religious Coping among Persons with Persistent Mental Illness. Psychiatric Services, 52, 660-665.

Uden, van M.H.F. \& Pieper, J.Z.T. (1996). Religie in de geestelijke gezondheidszorg [Religion in Mental Health Care]. Nijmegen: KSGV.

Uden, van M.H.F., Pieper J.Z.T. \& Alma, H.A. (2004). “Bridge over Troubled Water”. Further Results Regarding the Receptive Coping Scale. Journal of Empirical Theology, 17, 101-114.

Yangarber-Hicks, N. (2004). Religious Coping Styles and Recovery from Serious Mental Illness. Journal of Psychology and Theology, 32, 305-317. 